\title{
Study on the Socio-Personal and Economic Characteristics of Respondents among the Beneficiary in District Allahabad, India
}

\author{
Mayank Singh ${ }^{1 *}$, Ravi Pratap Singh ${ }^{2}$ and Anuj Tiwari ${ }^{3}$ \\ ${ }^{1}$ Department Agriculture Extension, Uday Pratap Autonomous Collage \\ Varanasi, U.P., 221002. \\ ${ }^{2}$ Horticulture, Collage of Horticulture \& Forestry, A N D U A\&T, \\ Kumarganj, Ayodhya, 224229, U.P. \\ ${ }^{3}$ Agricultural Extension, C.S.A University of Ag. \& Tech. \\ Kanpur, U.P 208002., India \\ *Corresponding author
}

A B S T R A C T

Keyw or d s
Socio-personal
communication

Communication is the major activity of human association in general and progress as well as development in particular. No human life can exist in isolation. A man can survive only in society and the survival in society is possible with communication. Therefore, communication is identified as the oldest continued activity of human being since birth and goes-on and on till death. More precisely, communication is the basic need of human being and web of society which makes the survival, growth, progress and development of man possible and holds the society intact and progressive. The study was conducted in purposively selected Allahabad district of Uttar Pradesh. Out of 20 CD Blocks only 5 CD blocks - Bahadurpur, Chaka, Handia, Meja and Soraon were selected randomly. Thereafter 2 villages from each selected CD block were selected by using stratified random sampling method. These selected villages were Andawa and Bhagipur of Bahadurpur, Dabhawn and Chaka of Chaka, Jagwawala and Aasepur of Handia, Jamwa and Detwa Kala of Meja and Juwnapur and Chaturipur of Soraon CD Block. Further, stratified random sampling was used for the selection of respondents of three categories of farmers. These three categories of respondents were large, medium and small farmers according to their possession of land. Total of 155 respondents of small 106 respondents of medium and 39 respondents of large land holders were selected in ratio proportion from selected villages.

\section{Introduction}

India is predominately agricultural country. Majority of population, about 60 per cent, of the country subsist on agriculture and its allied occupations and contributing 25 per cent to our national income. The early years of independence the country had witnessed wide spread food shortages compelling to import large quantity of food grains even under PL-84. The widespread famine, flood, starvations, sufferings and deaths India was branded as "basket case" or "ship to mouth" or "field-to mouth" or "begging bowl". After 
independence Indian policies, administration reformers, agricultural scientist made considerable and significant efforts to break the begging bowl to the present food surplus. The extensive efforts in this direction were witnessed through the Green Revolution which launched in mid-sixties when the production was only 74.2 million tonnes. India trebled the production of food grains upto 211.2 million tonnes by 2001-2002. It is worth to quote today India is the second highest producer of wheat in the world touching 76.4 million tonnes in 2000 A.D. Resultantly, India is able to raise its status among the comity of nations as one of the premier agricultural countries of the world. Due to large buffer stocks of foodgrains India is able to help generously countries which needed food, whether it is the war, drought, terrorism hazards and like. Today, India is the third biggest producer of food grains in the world. Scientists, and the planners, politicians, and responsibles of country have already realised to meet the future challenges of growing population of India by 2020 and even 2030 onwards. The futurology has been worked out and started implementing massive development programmes to modernise the agriculture through research and technology. It is clear that the main problem is not the lack of technology but its integration of farming practices in order to convert the information into production accomplishment. Vashistha (1987) stated that there are hundreds of extension programmes to reach millions of farmers in lakhs of villages. To fulfil the mission of any extension programme there is need to study the communication behaviour of the target audience. The communication behaviour refers the activity performed by an individual from the collection of information to final stage of its adoption. The communication behaviour is identified in three stages or communication behaviour is the outcome of three stages of activities performed by individuals. These three acts of communication are information input behaviour, information processing behaviour and information output behaviour. Therefore, there is need to find out the state of communication behaviour along with these three acts in terms of behaviour which affects the result of planned communication strateg.

\section{Materials and Methods}

Social research in general and behavioural research in particular requires systematic approach and procedures to accomplish the objectives of the study. Therefore it was imperative to adopt scientific research procedures, approved techniques, standardreliable and valid tools and appropriate statistical analysis of collected data to arrive at any conclusion in view of objectives of study. Besides the collection of primary data, baseline informations, reports, relevant official publications and other secondary sources as well as discussion with experts were also used as a source of additional relevant data.

\section{Research design}

Any social study when attempted systematically requires collection of place and people. Then the size of sample is determined in order to suit the study. The selection of place and people of study, here-in-after called locale/tract and respondents, requires an initial survey-collection of Bench mark data. The system which provides the method and steps to conduct the study as per its objectives is termed as research design.

\section{Locale of study}

The title of study clearly indicates that the study was conducted in Allahabad district of Uttar Pradesh state. The locale of study Allahabad district was selected purposively with following justification and limitations - 
1- The scholar being native of selected locale who is conversant with language, dialect, culture and background of the people as well as the area.

2- The research center being located in the district.

3- The study being academic, indepth and comprehensive.

4- All the headquarters of related organizations like Allahabad Agricultural Institute, Planning Office, Divisional Agricultural Office, Agro-economic Research Centre and like were located in Allahabad.

\section{Selection of CD blocks and villages}

Allahabad is administratively divided in 07 tehsils, $20 \mathrm{CD}$ blocks and 3539 villages. In view of objectives and research design of the study, it was not possible and appropriate to conduct the study in all the villages with in the specified period of present academic research. Therefore, the study was conducted in 10 villages of $5 \mathrm{CD}$ blocks.

\section{Selection of respondents}

India is country of diversities, so was the case with selected villages. There were various types of farmers belonging to different socioeconomic status, possession of holdings, caste, religion and so on. With a view to have comprehensive and indepth study all the farmers were selected as respondents on the basis of land holdings possessed by them. The three categories of land holders - large, medium and small were taken into account in view of objectives of study.

\section{Method of data collection}

After the establishing the rapport with the selected respondents, part I of the structured schedule was administered to collect the personal and socio-economic data of the respondents. Thereafter a gap of one week the part II of the schedule was administered to find out their level of extension contact and mass media exposure as per objectives of the study. Further, part III of the schedule was administered among the selected respondents after the gap of one week list out the constraints of communication which restricts individual to receive the desired information. The process of data collection including the preliminary informations and establishing the rapport was completed during February 2004 to March 2005.

\section{Statistical Analysis}

The scientific research requires accurately in results and contentions. Therefore statistical tests were applied to process the dates together the results and conclusions.

\section{Results and Discussion}

The status of the respondents was selected under systematic and standard techniques. The data presented in tables are related to personal and socio-economic characteristics of the respondents. More specifically the characteristics reveals the distribution of respondents according to their different categories of age, caste, education, possession of farm power, social status, economic status and socio-economic status.

Table.1 Distribution of respondents according to their age category

\begin{tabular}{|c|c|c|}
\hline S.No. & Age category & Frequency \\
\hline 1. & Young (18-35) & $142(47.33 \%)$ \\
\hline 2. & Middle (35-55) & $95(31.67 \%)$ \\
\hline 3. & Old (Above 55) & $63(21.00 \%)$ \\
\hline
\end{tabular}

Figure in parentheses indicates percentage 
Table 1 reveals that the majority of representation of respondents was of young age category followed by middle and old age categories. Their percentages of respondents were $47.33,31.67$ and 21.0 , respectively. The data clearly reveals that there was adequate representation of the respondents of all the age categories.

Table.2 Distribution of respondents according to their caste $\mathrm{N}=300$

\begin{tabular}{|c|c|c|}
\hline S.No. & Category & Frequency \\
\hline 1. & Scheduled Caste & $125(41.66 \%)$ \\
\hline 2. & Lower Caste & $67(22.33 \%)$ \\
\hline 3. & Artisan Caste & $2(0.67 \%)$ \\
\hline 4. & Prestige Caste & $92(30.67 \%)$ \\
\hline 5. & Dominant Caste & $14(4.67 \%)$ \\
\hline
\end{tabular}

Figure in parentheses indicates percentage

Table 2 reveals that the majority of respondents were of scheduled caste. Their total number were 125 respondents out of 300 selected respondents which accounted 41.66 per cent of the sample selected. There were 92 respondents who ever of prestige caste followed by 67, 14 and 2 respondents of lower caste, dominant caste and artisan caste, respectively. Their percentage out of total respondents were $30.67,22.33,4.67$ and 0.67 , respectively. It may be inferred from the table that there was scientifically appropriate representation of caste in the selected sample of the present study. The similar trend may be substantiated with the census statistics

Table.3 Distribution of respondents according to their level of education $\mathrm{N}=300$

\begin{tabular}{|c|c|c|}
\hline S.No. & Educational level & Frequency \\
\hline 1. & Illiterate & $41(13.67 \%)$ \\
\hline 2. & Can read only & $21(7.00 \%)$ \\
\hline 3. & Can read and write & $31(10.33 \%)$ \\
\hline 4. & Primary & $36(12.00 \%)$ \\
\hline 5. & High School and Intermediate & $89(29.67 \%)$ \\
\hline 6. & Graduation and above & $82(27.33 \%)$ \\
\hline
\end{tabular}

Figure in parentheses indicates percentage

Table 3 highlights that majority of respondents had schooling for their education. Their percentage was 69 whereas 17.33 per cent of respondents were able to read and write with result of NAEP and remaining 13.67 per cent respondents were illiterate. As far as their level of education of respondents was concerned, 29.67 per cent respondents had education upto High School and
Intermediate levels followed by 27.33 per cent respondents had education upto graduation and above. There were 17.33 per cent respondents who were able to read only (7.00 per cent) and read and write. The education upto primary was had by 12.00 per cent respondents. It is evident from the table that 86.33 per cent respondents were able give meaning to printed words. The data substiate 
the sayings that the Allahabad is centre of education. However, education is a never ending activity therefore farmers who are illiterate or neo-literates may be motivated or continuing their education.

Table.4 Distribution of respondents according to the possession of farm power

\begin{tabular}{|c|c|c|}
\hline S.No. & Tools & Frequency \\
\hline 1. & Drought Animal & $48(16.00 \%)$ \\
\hline 2. & Plough/Bullock & $116(38.66 \%)$ \\
\hline 3. & Pumping Set & $119(39.66 \%)$ \\
\hline 4. & Seed Drill Machine & $67(22.33 \%)$ \\
\hline 5. & Tractor & $37(12.33 \%)$ \\
\hline 6. & Combine & $9(3.00 \%)$ \\
\hline
\end{tabular}

Figure in parentheses indicate percentage

Table 4 reveals that 38.66 per cent of respondents had plough and bullocks. The pumping set was found among 39.66 per cent of respondents whereas seed drill machine was among 22.33 per cent of respondents. There were 16.00 per cent respondents who had draught animals. As far as tractor and combine were concerned, 12.33 per cent respondents had tractors and 3.00 per cent of respondents had combine.
It may be concluded that the sample selected for the present study had the representation of all the categories of farmers like marginal, small medium and big or large. There were the selected farmers as respondents who had only bullocks to cultivate the small piece of land and also the respondents who had tractors, pumping sets etc. The characteristics of sample increases the validity of the data.

Table.5 Distribution of respondents according to their social status N=300

\begin{tabular}{|c|c|c|}
\hline S.No. & Category & Frequency \\
\hline 1. & Low & $77(25.67 \%)$ \\
\hline 2. & Medium & $188(62.67 \%)$ \\
\hline 3. & High & $35(11.66 \%)$ \\
\hline
\end{tabular}

Figures in parentheses indicate percentage

Table 5 reveals that maturity of respondents were of medium social status followed by low and high social status. There were 188 respondents who had medium social status followed by 77 and 35 respondents who had low and high social status in the society. Their percentage was $62.67,25.67$ and 11.66, respectively. It may be concluded that more than 50 per cent respondents in the selected samples were of medium social status followed by more than half of the remaining respondents were of low social status.

It is therefore clear that the sample selected for the study had represented all the three sections of the society in ratio proportion which shows the authencity and validity of the sample for the study. 
Table.6 Distribution of respondents according to their economic status N=300

\begin{tabular}{|c|c|c|}
\hline S.No. & Category & Frequency \\
\hline 1. & Low & $128(42.67 \%)$ \\
\hline 2. & Medium & $127(42.33 \%)$ \\
\hline 3. & High & $45(15.00 \%)$ \\
\hline
\end{tabular}

Figures in parentheses indicate percentage

Table 6 presents the distribution of respondents according to their economic status. It was found that 42.67 per cent of respondents had low economic status closely followed by 42.33 per cent of respondents of medium economic status. There were 15 per cent of respondents who had high economic status. As far as the number of respondents of each economic status category was concerned there were 128 respondents who had low economic status closely followed by 127 respondents who were of medium economic status category and remaining 45 respondents had high economic status.

It may be concluded that the selected respondents had the representation of all the three sections of the society with appropriate and balanced size of sample in each category. The size of sample of each category may be substantiated with the census report of 2001.

Table.7 Distribution of respondents according to their socio-economic status $\mathrm{N}=300$

\begin{tabular}{|c|c|c|}
\hline S.No. & Category & Frequency \\
\hline 1. & Low & $90(30.00 \%)$ \\
\hline 2. & Medium & $160(53.33 \%)$ \\
\hline 3. & High & $50(16.67 \%)$ \\
\hline
\end{tabular}

Figures in parentheses indicate percentage

Table 7 reveals that majority of respondents had medium category of socio-economic status followed by the respondents of low and high socio-economic status. The category wise distribution of respondents highlights that there were 160 respondents who had medium socio-economic status followed by 90 and 50 respondents who had low and high socio-economic status. Their percentage was $53.33,30.0$ and 16.67 , respectively. It may be concluded that there was appropriate and balanced representation of respondents in the sample according to their socio-economic status.

The study was conducted in purposively selected Allahabad district of Uttar Pradesh. Out of $20 \mathrm{CD}$ Blocks only $5 \mathrm{CD}$ blocks -
Bahadurpur, Chaka, Handia, Meja and Soraon were selected randomly. Thereafter 2 villages from each selected CD block were selected by using stratified random sampling method. These selected villages were Andawa and Bhagipur of Bahadurpur, Dabhawn and Chaka of Chaka, Jagwawala and Aasepur of Handia, Jamwa and Detwa Kala of Meja and Juwnapur and Chaturipur of Soraon CD Block.

Further, stratified random sampling was used for the selection of respondents of three categories of farmers. These three categories of respondents were large, medium and small farmers according to their possession of IThe selected dependent variables were information input behaviour, information 
processing behaviour, information output behaviour communication behaviour and constraints of communication. Data were collected with help of structured interview schedule specially developed based on standard scales with modification in light of objectives and selected variables of study.

The developed schedule was pre-tested, made reliable and validated. The collected data was tabulated, classified and statistically processed by using mean, percentage, standard deviation, " $F$ " test and coefficient of correlation.

As far as extent of extension contact was concerned, majority of 80.67 per cent respondents had medium level of information input behaviour whereas low level of information processing behaviour and information output behaviour were had by majority of 62.33 per cent and 88.00 per cent respondents, respectively.

Information input behaviour and information output behaviour in relation to mass-media exposure was found at medium level among majority of 52.67 per cent and 60.67 per cent respondents, respectively. The information processing behaviour in relation to mass media exposure was found at low level among majority of 68.33 per cent respondents.

As far as overall communication behaviour was concerned, the information input, processing and output behaviours were found at medium level among majority of 67.00 per cent, 60.67 per cent and 58.00 per cent respondents, respectively followed by at low and high levels. The constraints of communication related to information input, processing and output behaviours were found at medium level among majority of 55.33 per cent, 65.34 per cent and 41.67 per cent respondents, respectively.

\section{References}

Ahmed, M.B. and Ali, M.M. (1999). Impact of farmers communication behaviour on types of information generated in BSfarmer. Annals of Bangladesh Agriculture, Vol. 8, No. 2, pp. 119-127.

Ahsan, E., Huda-ANMS, Ahmed, N., Rahman, S. (1991). Bangladesh's Second Extension and Research Project. Public Administration and Development. Vol. 11, No. 3, pp. 207209.

Akhouri, M.M.P. (1973). Communication Behaviour of Extension Personnel : An Analysis of Haryana Agricultural Extension Services; Ph.D. Thesis, Division of Agricultural Extension, I.A.R.I., New Delhi.

Akhoury, M.M.P. (1973). Communication Behaviour of Extension Personnel, An Analysis of Haryana Agricultural System. Unpublished Ph.D. Thesis, Division of Agril. Extension, IARI, New Delhi.

Dimri, Adita and Sujan, D.K. (1986). A study of communication behaviours, folk culture and oral traditions in Garhwal division of Uttar Pradesh. Unpublished M.Sc. thesis, Department of Agricultural Communication, G.B. Pant University of Agri. \& Tech., Pant Nagar.

Gaikwad, V.K., Tripathi, B.L. and Bhatnagar, G.S. (1972). Opinion leaders and communication in India villages : Centre of Management in Agriculture; Indian Institute of Management, Ahmedabad.

Jacobscon, Thomas L. (1991). "Theories as Communication" Communication Theory, 1(2) : 145-150.

Jha, P.K., Chauhan, J.P.S. (1999). Correlates of interpersonal communication behaviour of dairy farmers in north Bihar. Journal of Dairying, Foods and 
Home Sciences, Vol. 18, No. 1, pp. 5557.

Kadian, K.S. and Kumar, Ram (2003). Information processing pattern of dairy farmers of Kangra Valley. India Journal of Extension Education, Vol. XXXVIII (1\&2) : 65-70.

Martinez Ruiz, J., Sanchez Izquierdo, M.A. (1997). Communication as a means of making growers participants in sustainable development. Sustainable irrigation in areas of water scarcity and drought. Proceedings of the International Workshop, Oxford, U.K., pp. 14-22.

Mehta, S.K., Sardana, P., Mehta, U.P. (1996). Communication behaviour of cotton growing farmers in Haryana. Crop Research Hisar, Vol. 11, No. 1, pp. 120127.

\section{How to cite this article:}

Mayank Singh, Ravi Pratap Singh and Anuj Tiwari. 2020. Study on the Socio-Personal and Economic Characteristics of Respondents among the Beneficiary in District Allahabad, India. Int.J.Curr.Microbiol.App.Sci. 9(03): 288-295. doi: https://doi.org/10.20546/ijcmas.2020.903.033 